\title{
On the retirement of an eminent scientist in fisheries and aquatic science in Sri Lanka: a personal approach
}

\author{
Upali S. Amarasinghe \\ Department of Zoology and Environmental Management, University of Kelaniya, Kelaniya 11600, \\ Sri Lanka \\ Correspondence (zoousa@kln.ac.lk) \\ http://orcid.org/0000-0002-0465-6950
}

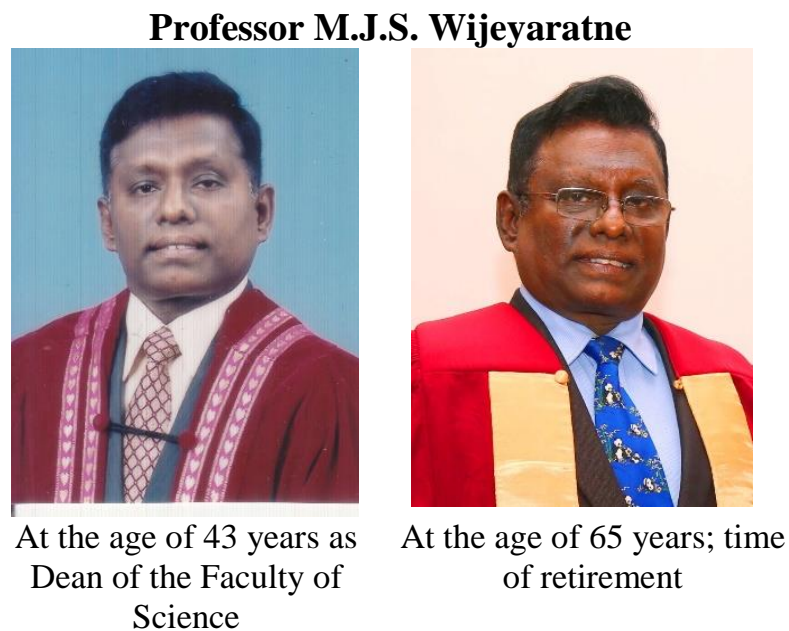

The current issue of Sri Lanka Journal of Aquatic Sciences is dedicated to Professor M.J.S. Wijeyaratne (Department of Zoology \& Environmental Management, University of Kelaniya, Sri Lanka) for his 40 years of uninterrupted contribution to research on fisheries and aquatic sciences in Sri Lanka. After his secondary school education at Royal College, Colombo, he entered the University of Sri Lanka, Vidyalankara Campus and was graduated with BSc Special degree in Zoology in 1975 with a Second Class Upper Division Honours. After joining the Vidyalankara Campus of the University of Sri Lanka (presently University of Kelaniya) as a probationary lecturer in 1976, he won the Fulbright scholarship and obtained MSc degree in the field of Natural Resources from University of Michigan, USA in 1978 and subsequently $\mathrm{PhD}$ from University of Kelaniya in 1984. During his career,
Professor Wijeyaratne has so far authored 100 research papers in indexed journals and scholarly volumes, 14 textbooks and edited volumes, 97 research communications and also contributed as a consultant for 81 development projects both in Sri Lanka and overseas.

University of Kelaniya has recently celebrated $50^{\text {th }}$ anniversary of the Faculty of Science. After establishment of the Faculty of Science in this university in 1967, the research culture in the Sri Lankan university system has moved towards a new paradigm, especially in the field of fisheries and aquatic sciences. Professor H.H. Costa, the founder Professor of Zoology in the University of Kelaniya (then Vidyalankara University) was instrumental to make the Department of Zoology in University of Kelaniya the Centre of Excellence in research on fisheries and aquatic sciences in Sri Lanka. Professor Wijeyaratne was the first BSc Honours 
degree student in Zoology in this university and once joined the department, he shouldered the responsibility of maintaining the status quo.

Scientific publications manifest a marked turning point in the early 1980s, in research on fisheries and aquatic sciences in Sri Lanka. Analytical approaches for inland and estuarine as well as marine fisheries in Sri Lanka first appeared during this period (Wijeyaratne and Costa 1981, 1986, 1987; Amarasinghe et al. 1983; Wijeyaratne and Amarasinghe 1987; Karunasinghe and Wijeyaratne 1991).

Professor Wijeyaratne served as the Dean of the Faculty of Science and the Vice-Chancellor of the University of Kelaniya. He is a Chartered Biologist, Fellow of the Institute of Biology of Sri Lanka (IOB) and a Fellow of the National Academy of Science of Sri Lanka (NASSL). He has served as the General President of Sri Lanka Association for Advancement of Science (SLAAS), President of IOB, Founder President of Sri Lanka Association for Fisheries and Aquatic Resources (SLAFAR), General Secretary of NASSL and also as the Chairman of the Committee of Vice-Chancellors and Directors (CVCD) of Sri Lanka. He has been serving in the Governing Boards of many Science \& Technology (S\&T) and Research \& Development (R\&D) Institutions of Sri Lanka, including National Science Foundation, National Aquatic Resources Research \& Development Agency, National Institute of Fisheries and Nautical Engineering which was the predecessor of institution of Ocean University, Sri Lanka Standards Institution, Arthur C Clarke Institute for Modern Technologies, Industrial Technology Institute and National Institute of Fundamental Studies. He was also the Chairman of the National Science and Technology Commission of Sri Lanka.

Professor Wijeyaratne has won several awards for his scientific research. They include the prize for the best young scientist in biology awarded by the TWAS World Academy of Sciences, Trieste, Italy in 1989, Kottegoda Memorial Oration Gold Medal in 1999 awarded by SLAAS, the most outstanding senior researcher in biology award 2010, which is a lifetime award by the CVCD of Sri Lanka. Furthermore, he has won presidential awards for scientific research in several occassions.

He was the editor-in chief of Sri Lanka Journal of Aquatic Science for its first 10 volumes. He was later appointed as the Honorary Editor of the journal. With all these roles in various scientific bodies in the country, Professor Wijeyaratne has been contributing immensely to the development of Science \& Technology sector in Sri Lanka.

$\mathrm{He}$ is one of the six scientists in the field of fisheries and aquatic science in Sri Lanka, whose hindex (according to Google Scholar Citations) is greater than 12. Three of them (including Professor Wijeyaratne) are from the Department of Zoology and Environmental Management, University of Kelaniya, one is from University of Sri Jayawardenepura, one from University of Ruhuna and one is a retired scientist from the National Institute of Fundamental Studies. Service of eminent scientists like Professor Wijeyaratne therefore is indispensable. While wishing him a healthy and peaceful retirement, I reiterate the fact that sensible mechanisms should be put in place to receive input of scholars of the caliber of Professor Wijeyaratne beyond their retirement.

\section{REFERENCES}

Amarasinghe, U.S., H.H. Costa and M.J.S. Wijeyaratne 1983. Limnology and fish production potential of some reservoirs in Anuradhapura district, Sri Lanka. Journal of Inland Fisheries 2: 14 -29

Karunasinghe, W.P.N. and M.J.S. Wijeyaratne 1991. Selectivity estimates for Amblygaster sirm (Clupeidae) in the small meshed gill net fishery on the west coast of Sri Lanka. Fisheries Research 10: 199-205.

Wijeyaratne, M.J.S. and U.S. Amarasinghe, 1987. Estimations of maximum sustainable fish yields and stocking densities of fish fingerlings in freshwater lakes and reservoirs. Archiv für Hydrobiologie-Beiheft Ergebnisse der Limnologie 28: 305-308.

Wijeyaratne, M.J.S. and H.H. Costa 1981. Stocking rate estimates of Tilapia mossambica fingerlings for some inland reservoirs of Sri Lanka. Internationale Revue gesamten Hydrobiologie 66: 327-333.

Wijeyaratne, M.J.S. and Costa, H.H. 1986. Application of "yield per recruit" and "surplus yield" models to the grey mullet fishery in Negombo lagoon, Sri Lanka, Journal of Inland Fisheries 3: 3-14. 